\title{
CONCEPTUAL EXPLORATION ON INTERNAL COMMUNICATION AND ORGANIZATIONAL IDENTIFICATION AS DETERMINANTS OF EMPLOYEE PERFORMANCE
}

\author{
Nuzatul Shima Sulaiman ${ }^{1}$ \\ Human Communication, Faculty of Modern Languages and Communication, \\ Universiti Putra Malaysia (UPM), Malaysia. \\ (Email: shima_mpi@yahoo.com) \\ Zulhamri Abdullah ${ }^{2}$ \\ Human Communication, Faculty of Modern Languages and Communication, \\ Universiti Putra Malaysia (UPM), Malaysia. \\ (Email: zulhamri@upm.edu.my)
}

Received date: $12-05-2019$

Revised date: 19-09-2019

Accepted date: 09-10-2019

Published date: 10-10-2019

To cite this document: Sulaiman, N. S., \& Abdullah, Z. (2019). Conceptual Exploration on Internal Communication and Organizational Identification as Determinants of Employee Performance. International Journal of Modern Trends in Social Sciences, 2(9), 99-115.

DOI: $10.35631 /$ IJMTSS.29009

\begin{abstract}
Recent studies indicate internal communication and organizational identification are the pressing needs of organizations to achieve employee performance and organizational effectiveness. Despite an extensive number of studies, the concepts of internal communication and organizational identification and their link to employee performance are still understudied particularly on the impact of organizational effectiveness. Understanding the mechanisms by which internal communication influences employee performance also remains scarce in the literature. Thus, this paper is prepared to ascertain the influence of two factors; internal communication as the communication factor and organizational identification as the social factor in terms of enhancing employee performance. A wideranging search of the three concepts is explored, examined their relationships and proposed with an underlying mechanism for the relationship. Adopting symmetrical internal communication, social identity and social exchange theories from the perspective of employee communication behavior, this paper reviews and analyses the effects of internal communication and organizational identification on employee performance by providing an integrative conceptual framework and suggesting an improved direction for future research. Theoretically, this paper provides a comprehensive insight into the existing literature that offers the basis for a rigorous assessment of internal communication and organizational identification influences on employee performance. Practically, the conceptual model may provide communication managers with the crucial guidelines for designing and implementing appropriate internal communication and identification programs for the success of employee performance and organizational sustainable development.
\end{abstract}


Keywords: Internal Communication, Organizational Identification, Employee Performance, Employee Engagement

\section{Introduction}

In recent decades, internal communication and organizational identification have become central of communication studies due to the pressing needs by organizations to achieve employee performance and organizational effectiveness. Scholars recognize the two constructs as new key determinants of employee performance because of the effectiveness of internal communication as a leading indicator of organizational success (Ehling et al. 1992; Ruck and Welch, 2012) and the essential of organizational identification for effective functioning (Fuller et al., 2006).

There is a steady stream of studies examining links between internal communication and organizational performance (e.g Grunig et al., 2002; Yates, 2006; Morris, 2010; Bakker et al., 2011; Welch, 2011; Meng and Berger, 2012; Jiang and Men, 2015; Kang and Sung, 2017). Internal communication has the potential to effectively convey the values of the organization to all employees, involve them with the goals of the organization and results in more engaged employees (Bindl and Parker, 2010). Meanwhile, identification is also proven as an important component of an employee's professional life and influences their ability to engage with their work (Karanges et al., 2014).

As employee performance, enhanced by employee engagement (Macey and Schneider, 2008; Rich et al., 2010) has emerged as a new paradigm within which organizations are trying to integrate, interact and collaborate with their stakeholders (Edelman, 2008; Taylor and Kent, 2014), effective internal communication is vital to strengthen employees' identification (Smidts et al., 2001) and boosting their motivation in order to get more involved in achieving the goals (Dutton et al., 1994; Karanika-Murray et al., 2015). In other words, organizations should focus internal communication efforts toward building greater perceptions of support and stronger identification among employees in order to foster optimal levels of engagement (Karanges et al., 2014).

However, in spite of the importance of the relationship between internal communication and employee performance; and the relationship between organizational identification and employee performance, there have been few studies linking the two concepts concurrently to employee performance. While many empirical, theoretical and conceptual articles have examined work environment, leadership, team and co-worker and HRD practices as drivers of employee engagement (Anitha J., 2014; Rana et al., 2014), it could not be identified any extant studies that add the elements of internal communication and organizational identification to the drivers and employee engagement in one holistic model. Also, internal communication has been posited as an important factor in the development of employee engagement (Welch, 2011) but however, understanding the mechanisms by which internal communication influences employee engagement remains scarce in the literature.

Moreover, the literature has also not adequately addressed the close link between internal communication and identification factors to employee performance. The importance of the two factors is underscored by findings and statements such as internal communication was an important driver of employee engagement (Morris, 2010; Welch, 2011; Jiang and Men, 2015); there is a positive connection between communication climate and organizational identification (Smidts et al., 2001; Bartels et al., 2010); and internal organizational 
communication influences employees' ability to identify with their organization which then has an expositive impact on employee engagement (Karanges et al, 2014). These statements and others like them in communication literature implicitly assume that the effects of internal communication and organizational identification apply across situations related to engagement, but this assumption has not been extensively tested so far.

This study is particularly important as the relationship of internal communication, organizational identification and employee performance needs further explanation. As concerned by Epitropaki (2013), organizational identification has become a cohesive force for maintaining the relationship between employee and employer in today's increasingly complex and boundaryless organizations. Thus, in order to create an identity in a workplace without boundaries that distinguishes organizations from others and ties employees more closely to them, effective internal communication is required to strengthen employees' identification with their organizations (Smidts et al., 2001) to boost employee's motivation and getting more involved in achieving the goals by engaging with their work (Dutton et al., 1994; Karanika-Murray et al., 2015). Such inter-related roles of internal communication and organizational identification lead to the urgent needs to study and understand the reasons for the combined roles and in what ways and to what extent organizations can manipulate them to influence the performance of their employees.

In response to the research gap, it is the purpose of this paper to examine the direct relationship of internal communication and organizational identification with employee engagement as well as the relationship between internal communication and organizational identification. Specifically, this paper analyses both internal communication and organizational identification as inter-correlated concepts and proposed as key determinants of employee performance. At the end of discussion, this paper comes up with a comprehensive and holistic conceptual model that links the key determinants with employee performance as the outcome of employee engagement and concludes with significance of the study.

\section{Literature Review}

This paper is guided by relevant past research findings and the value of internal communication and organizational identification best practices related to employee performance. It begins with reviewing the literature related to the three concepts and based on relevant theoretical backgrounds, it discusses the nature of their relationship and provide reasons for considering the two concepts - internal communication as communication factor and organizational identification as social factor concurrently related to employee performance. Then, it discusses a holistic conceptual model that link and combine the three concepts altogether.

\section{Relationship of Internal Communication and Employee Performance}

Internal communication, sometimes called employee communication or internal public relations (Kennan and Hazleton, 2006; Kreps, 1989) has been recognized as the foundation for modern organizations which helps achieve positive relations with external publics (Cutlip et al, 2005). It is defined as communication between the organization's leaders and one of its key publics - the employees (Dolphin, 2005). It is also a social interaction through messages (Kalla, 2005) and reflects management's ability to build relationships between internal stakeholders at all levels within an organization (Welch and Jackson, 2007).

In response to the changing business and marketing environment, the formal and informal internal communication practices have been eventually shifted toward being strategically 
aligned with organizational goals, visions and values. Despite the wealth of research supports the link between internal communication and organizational effectiveness such as job satisfaction, productivity and leadership, Welch and Jackson (2007) found that internal corporate communication lacks theoretical clarity particularly from strategic management perspective. They have positioned internal communication within the strategic public relations and introduced a model of internal corporate communication which is adapted from Van Riel (1995). With the two efforts, they deliberately define internal corporate communication as a process between an organization's strategic managers and its internal stakeholders, designed to promote commitment to the organization, a sense of belonging to it, awareness of its changing environment and understanding of its evolving aims (Welch and Jackson, 2007).

Kang and Sung (2017) found out a more strategic internal communication related to employee engagement recently. Adopting Grunig's theory (1992), they empirically discovered symmetrical internal communication is linked with employee engagement which enhances supportive employee communication behaviours and reduces turnover intention. In other words, in order to facilitate employees' engagement and favourable communication regarding an organization, the organization needs to practice a two-way, employee-centred symmetrical communication system in its everyday communication management.

In explaining employee engagement, research has principally shown a major contribution of employee engagement is it enhances employee performance (Macey and Schneider, 2008; Rich et al., 2010). Employee performance has been mentioned as a positive consequence of employee engagement in an extensive number of employee engagement studies. The reason behind this is engaged employees exhibit a wide range of productive behaviour that enhance synergetic team efforts toward organizational goals (Bakker and Demerouti, 2008; Bakker et al., 2006) which lead to enhanced employee performances (Bakker and Schaufeli, 2008). As a result of the interrelated nature of "engagement" and "performance", both terms are used interchangeably in the discussion of this study.

One of the first scholars studying engagement, Kahn (1990) defined personal engagement as the harnessing of organization members' selves to their work roles; in engagement, people employ and express themselves physically, cognitively, and emotionally during role performances. From the perspective of organizational behaviour, Schaufeli et al. (2002), defined engagement as a positive, fulfilling, work-related state of mind that is characterized by vigour, dedication, and absorption where engaged employees are energetic and connected with their work activities and feel they are capable of accomplishing those tasks (Schaufeli et al., 2008). Shuck and Wollard (2010), however agreed with Kahn and defined engagement as an individual employee's cognitive, emotional, and behavioural state directed toward desired organizational outcomes.

Truss et al. (2006) adopted Kahn's (1990) definition and empirically developed three different levels of engagement which include emotional (being very involved in work related tasks), cognitive (focusing very hard on work related tasks), and physical (being willing to put in extra effort). That is to say, Truss et al. (2006) believe that when engaged, people employ and express themselves physically, cognitively and emotionally during role performance. But, prior to that, they may need internal communication as mechanism to fulfil three main drivers of employee engagement they suggested which are: opportunities for employees to feed their views and ideas upwards, employees feeling well-informed about 
what is happening within their organization and employees sensing their manager is committed to the organization.

The view of internal communication as mechanism is in line with Kress (2005) and Lockwood (2007) as cited by Kang and Sung (2017) that the values of excellent internal communication have been noted in fostering better relationships with employees and espousing employee engagement. In previous studies, the said relationship has been explained based on Grunig's symmetrical communication theory (2001) who conceptualizes it as a willingness of an organization to listen and respond to the concerns and interests of its key stakeholders; and for this kind of relationship, Grunig (2001) emphasizes that organizations need to approach their employee relations similarly to their relations with other key stakeholders. The symmetrical system of internal communication has also been argued as the most ethical model (Dozier et al., 1995) and empirically tested linked to employee engagement (Kang and Sung, 2017; Men, 2014; Jo and Shim, 2005).

Furthermore, according to Dozier et al. (1995), symmetrical communication theory underscores the importance of negotiating and listening with a willingness to make an internal change. In describing the relationship between internal communication and employee engagement, the theory explains symmetrical communication creates a sense of open communication between the organization and the employees in order to build trust and to promote mutual understanding, respect and strong relationship. Emphasis is placed on finding a compromise between the interests of the organization and the employees. This strategic relationship management with internal publics affects overall management effectiveness. When employees feel satisfied and engaged in the organization, it is presumed that they will be more likely to develop positive relationships with other stakeholders both within and beyond the firm, thus exhibiting engagement (Mishra et al., 2014). Gradually, employee communications could ultimately produce quality employee relationships and when the employees develop relationships with external stakeholders, they can become the ambassadors or advocates for the firm (Chong, 2007; Grondstedt, 2000).

A review of existing literature suggests the following attributes or characteristics of internal symmetrical communication:

- Trust, credibility, openness, reciprocity, network symmetry, horizontal communication, feedback and negotiation - as stated in Grunig (1989), cited in Kim and Rhee (2011);

- Transparent - as cited in Men (2014), “...certain internal organizational practices such as symmetrical and transparent communications with employees have been found to be associated with good EOR quality"; and

- Consistency - as cited in Lockwood (2007) “...transparent and consistent internal communication from the management was an important driver of employee engagement".

Whereas the attributes of employee engagement lead to their performance are based on Kahn (1990) and Truss et al. (2006):

- Emotional (being very involved in work related tasks);

- Cognitive (focusing very hard on work related tasks); and

- Physical (being willing to put in extra effort).

Therefore, with regard to the relationship between internal communication and employee performance, this paper hypothesizes: 
H1: Internal communication is positively related to employee performance.

\section{Relationship of Internal Communication and Organizational Identification}

Internal communication facilitates interactions between organizations and employees which create social relationships based on meaning and worth (Smidts et al., 2001). In turn, this is believed to promote employee understanding of the goals of the organisation and enable them to identify with the values of the organisation (Welch, 2011).

Employees who are identified with their organizations develop feelings of connectedness and being part of something greater (Ashforth et al., 2008). It can reduce uncertainty because it provides them with a sense of order (Hogg, 2000) and is an important part of a person's selfconcept (Ashforth, 2001; Deaux et al., 1999; Hogg, 2000). Thus, for organizations, having employees who identify with the organization is vital because organizational identification can increase loyalty, decrease turnover-intentions, prevent alienation, lead to more work satisfaction, and in general increase performance (Ashforth et al., 2008; Haslam, 2001).

A prominent definition by Mael and Ashforth (1992) describes organizational identification as the perception of oneness with or belongingness to an organization, where the individual defines him or herself in terms of the organization (s) in which he or she is a member. Dutton et al. (1994) also agreed to define organizational identification as the degree to which a member defines him - or herself by the same attributes that he or she believes define the organization. In other words, when an employee identifies him/herself with the organization, he or she develops emotional ties with the organization and this often results in positive outcomes such as, organizational citizenship behaviour (Dukerich et al., 2002; van Dick et al., 2008; Restubog et al., 2008), creative behavior (Carmeli et al., 2007), job satisfaction and job involvement (van Knippenberg and van Schie, 2000).

Furthermore, organizational identification is conceived as a combination of both cognitive and affective components (Riketta, 2005). Based on O'Reilly and Chatman's (1986) approach of affective components of organizational identification, Riketta (2005) considers organizational identification as the desire to maintain an emotionally satisfying self-defining relationship with the identification object while for cognitive connection, as sharing attributes between a person's self-concept and the perceived organizational identity (Dutton et al., 1994).

The discovery of organizational communication positively related to organizational identification is mainly found in Bartels et al.'s study (2007). Formerly, part of previous research only suggests that information signalling the organizational identity can increase organizational identification because it helps individuals to see themselves as part of the organization they work for (e.g., Postmes et al, 2001) while the rest of studies show that a positive and open communication climate in which individuals feel valued and appreciated is important (e.g., Smidts et al., 2001). But to no avail, little is known about which aspects in organizational communication foster organizational identification.

Bartels et al. (2010) further discuss the aspects of vertical and horizontal communication in their study. According to them, the two aspects of internal communication lead to different impacts to organizational identification. The dimensions of vertical communication are important predictors of organisational identification, whereas dimensions of horizontal communication are important predictors of professional identification (Bartels et al., 2010). 
Vertical communication is work-related and travels top-down and bottom-up within the organisation's hierarchy (Downs and Adrian, 2004; Goldhaber, 1993). Top-down communication mainly is comprised of information regarding the organisation's strategy while bottom-up communication is the information sent from the work floor to management level and encompasses, for example, employee opportunities to participate in decisionmaking (Bartels et al., 2010).

Thus, adopting Bartel's study, this study expands and explores more on the aspect of vertical communication as it is a positive connection between communication climate and organizational identification (Smidts et al., 2001). In addition, Postmes et al. (2001) also supported commitment can be better explained through vertical than horizontal communication.

Vertical communication was discovered to be a stronger predictor of commitment than horizontal communication (Bartels et al., 2010) because it can reduce uncertainty about the organisation's stance and help employees to comprehend and define what it stands for (Postmes et al., 2001). Employees will be well-informed about the organisation's mission, goals and accomplishments make them recognise the organisation's specific characteristics (Dutton et al., 1994). Vertical communication also allows the organisation to inform its employees about how it distinguishes itself from other organisations (Ashforth and Mael, 1989; Cheney, 1983; Postmes, 2003). Thus, vertical communication is necessary to communicate the distinguishing characteristics of an organisation (Smidts et al., 2001), which may then contribute to employees' organisational identification (Bartels et al., 2010).

The impact of vertical communication on organizational identification can be better explained by social exchange theory. Social exchange theory is a prominent theoretical paradigm for understanding workplace relationships (Cropanzano and Mitchell 2005) and employee attitudes (DeConinck 2010) and offers a lens to explore social exchange relationships within the organizational environment (Gersick et al., 2000). Social exchanges involve a sequence of interactions between two parties that produce personal obligations, appreciation and trust (Blau 1964; Emerson, 1976). The most significant characteristic of social exchange is reciprocity, whereby positive and fair exchanges between two parties (individuals or groups) result in favourable behaviours and attitudes (Cropanzano and Mitchell 2005).

The conceptualization of information as a resource of exchange in vertical communication is consistent with social exchange theory because employees use their cognitive filters to translate resources (i.e., information) into positive or negative actions (Karanges et al., 2014). For instance, employees exchange information and views not only to learn what others think or to obtain information that enables them to do their task (Postmes, 2003) but rather, they actively engage in collective sense-making in order to reduce the uncertainties they face and through this process they simultaneously define what is consensual and normative within the group (Weick and Roberts, 1993). This means the more symmetrical organizations and employees communicate, the more employees desire to reciprocate favours toward their organization which result in the more power the relationship, the higher is the workflow (Mohr and Nevin, 1990).

From the above discussion, by excluding the horizontal communication element, the literature suggests vertical communication and symmetrical communication may share similar attributes which are: 
- Trust, credibility, openness, reciprocity, network symmetry, feedback and negotiation - as stated in Grunig (1989);

- Transparent - as cited in (Men, 2014), “...certain internal organizational practices such as symmetrical and transparent communications with employees have been found to be associated with good EOR quality" ; and

- Consistency - as cited in Lockwood (2007) “...transparent and consistent internal communication from the management was an important driver of employee engagement".

Whereas the attributes or characteristics of organizational identification, as defined by Smidts et al. (2001), Tajfel and Turner (1985) and Edwards (2005) are:

- The cognitive component - refers to a person's self-definition in terms of his or her organizational membership

- The affective component - refers to the emotional attachment to the group, and the feelings one has about this membership, including pride, appreciation, and belongingness

Thus, with regard to the relationship between internal communication and organizational identification, this study hypothesizes:

$\mathrm{H} 2$ : Internal communication is positively related to organizational identification.

\section{Relationship of Organizational Identification and Employee Performance}

Internal corporate communication as modelled by Welch (2011) involves organizational practices designed to promote employee understanding of the goals of the organization and enable them to identify with the values of the organisation. Such practices are recognised as key influences for employee performance (Bindl and Parker, 2010) since they enable internalization of organizational values and involvement with organisational goals, resulting in more engaged employees (Welch, 2011). Apart from internal corporate communication, Welch (2011) also recommended further work could consider how employee engagement is connected to other important constructs such as organisational culture or organizational identity.

Identity and identification are root constructs in organizational phenomena and have been a subtext of many organizational behaviours (Albert et al., 2000). There has been little published research on the direct link between work engagement and organizational identification (Karanika-Murray et al., 2015). However, the organizational behaviour literature supports a possible link between the two. Tyler and Blader (2001) discover that employees with strong group identification tend to have greater motivation to cooperate with their group, both directly and indirectly through the influence of identity on attitudes and values. Reade (2001) also showed that organizational identification can directly predict increased motivation and performing beyond an individual's core tasks. In other words, individuals who have strong identification with their organization are more likely to be actively involved in its goals and activities, and in turn be more motivated to work harder to achieve these goals (Dutton et al., 1994).

Apart from the concept of organizational identification, researchers have related perceived organizational support as a social factor of employee performance in their studies. A recent study by Nazir and Islam (2017) viewed that organizations showing concern toward perceived organizational support can create a sense of duty among employees who reciprocate with higher levels of work engagement. Perceived organizational support is the 
extent to which an employer cares about his/her employees' well-being and values their contributions and it improves employees' productive contributions with the help of evaluative feedback and results in more engaged employees (Eisenberger et al., 2001). However, even though perceived organizational support is considered one of job resources and social supports in engaging employees (Eisenberger et al., 2001), the current research on it has not considered another important aspect of an employee's professional life, specifically their sense of identity and belonging (Sluss et al. 2008).

Employees' sense of identity to their organization can be interpreted as organizational identification. Identification is commonly referred to as an employee's perception of oneness and group membership and has the potential to influence social exchange relationships (Ashforth and Mael 1989). Organizational identification particularly occurs when employees feel as though they belong to an organization, whereby they identify themselves in terms of their social and group membership (Tajfel 1978). In addition, employees who identify themselves with the organization view the success or failure of the organization as their own (Ashforth and Mael 1989).

The effects of organizational identification on employee engagement and performance can be described by social identity theory as much of the research examining organizational identification has been influenced both by social identity theory and the literature regarding group identification processes (Smidts et al., 2001; Fuller et al., 2006a). Social identity theory suggests that a strong bond between an employee and their organization reinforces their motivation to exert effort for (and on behalf of) their colleagues and their organization (Ashforth and Mael, 1989; Dutton et al., 1994). This is due to organizational identification has a cognitive and affective component which influences an employee's sense of pride and belonging to an organization (Smidts et al. 2001; Tajfel and Turner 1985). The two components take a central role in most conceptualizations: the cognitive component that refers to a person's self-definition in terms of his or her organizational membership, and the affective component that refers to the emotional attachment to the group, and the feelings one has about this membership, including pride, appreciation, and belongingness (Edwards, 2005). Between the two components, according to Tajfel and Turner (1985) the affective component of organizational identification plays the more important role in achieving positive social identity. Thus, as a positive outcome, stronger psychological bond with the organization can reinforce willingness to perform better and to engage with work itself (Karanika-Murray, 2015).

Therefore, with regard to the relationship between organizational identification and employee performance, this study hypothesizes:

H3: Organizational identification is positively related to employee performance.

\section{Relationship of Internal Communication, Organizational Identification and Employee Performance - The Conceptual Model}

As suggested by Dasgupta et al., (2012), interpersonal relationship including social relations with one another are an essential part of organizational life and sustainable success and supported by Postmes (2014) that communication serves essential functions ranging from the maintenance of interpersonal relations among co-workers to the dissemination of strategic organizational objectives, this present paper proposes that social factor (i.e identification) and communication factor (i.e internal communication) should come simultaneously and a conscious connection should be established between the two constructs and employee performance. 
Building on the three main hypotheses as well as adopting social exchange theory, this paper specifically suggests that internal symmetrical communication comprising of trust, transparent and consistency attributes influence the emotional, cognitive and physical engagement of employees. Concurrently, in accordance with social identity and social exchange theories, internal symmetrical communication affects the cognitive and affective components of organizational identification whereby employees with strong identification tend to have greater emotional, cognitive and physical engagement and perform better in their core tasks.

Consequently, the discussion above leads to a one way the relationship of internal communication, organizational identification and employee performance can be conceptualised. Figure 1 shows a conceptual model that can be viewed from communication and social perspectives which provides a platform for future communication research.

Figure 1: A Conceptual Model of Internal Communication and Organizational Identification as Determinants of Employee Performance

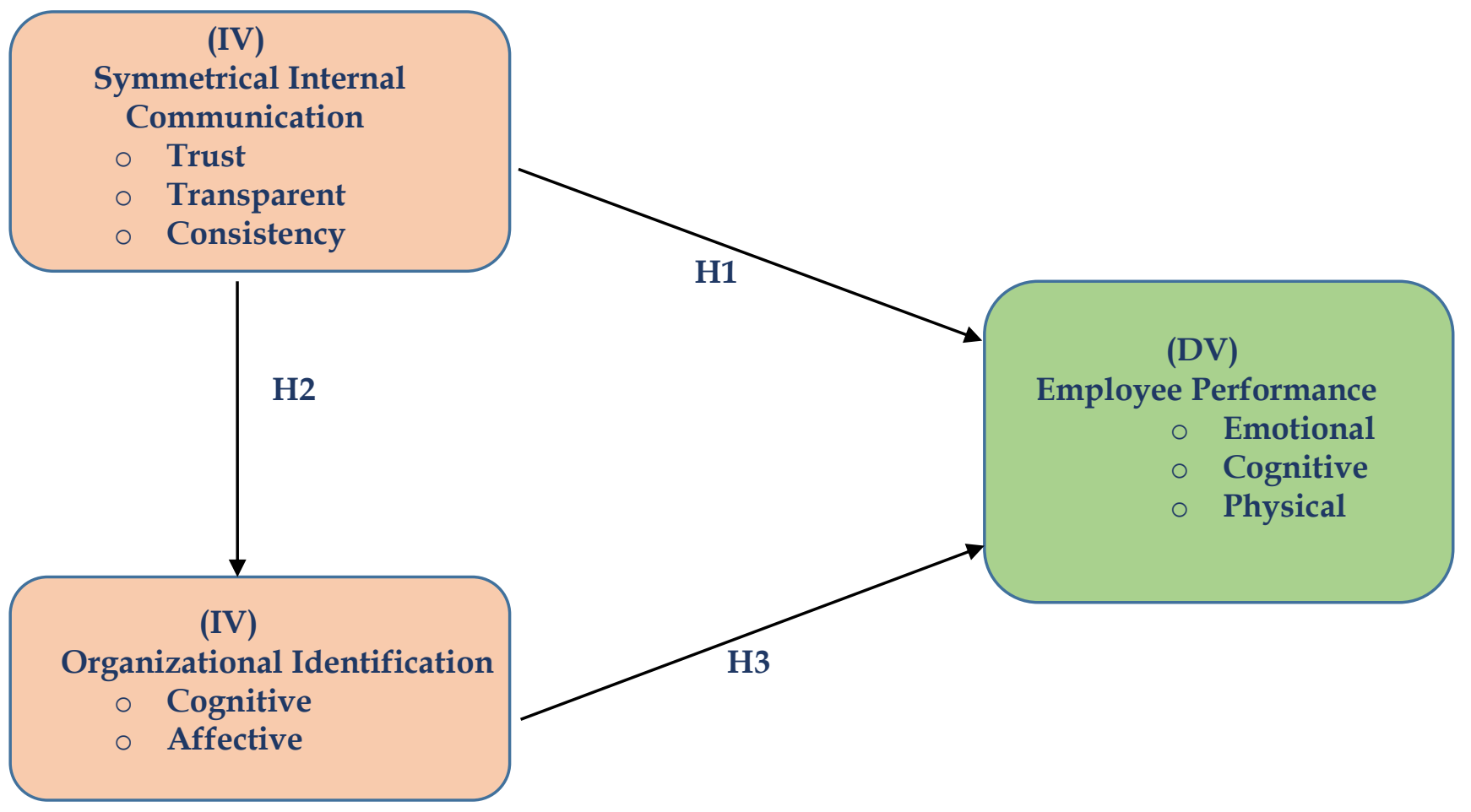

H1 : There is positive relationship between internal communication and employee performance (Sources: Kang \& Sung, 2017; Jiang and Men, 2015; Morris, 2010; Welch and Jackson, 2007)

$\mathrm{H} 2$ : There is positive relationship between internal communication and organizational identification (Sources: Bartels et al., 2010; Postmes, 2003; Ashforth and Mael, 1989); and

H3 : There is positive relationship between organizational identification and employee performance (Sources : Karanika-Murray et al., 2015; Karanges et al., 2014). 


\section{Significance of the Study and Conclusion}

The drivers of employee performance have long been identified as perceived support, job characteristics and value congruence (Karanges et al., 2014) but ample evidence has shown the inter-related concepts of internal communication and organizational identification as new key determinants in enhancing employee performance efforts. This paper contributes a model which conceptualises these relationships - between internal communication, organizational identification and employee performance. In a more specific way, the model suggests the concept can also be viewed from communication and social perspectives and thus provides a starting point for further research.

More importantly, apart from internal communication being acknowledged as key communication influence of employee engagement, this paper recognises that scholars have begun to consider organizational identification as key social influence in enhancing better levels of employee engagement. Scholars emphasised that the influence in a specific form of social identification (Ashforth and Mael, 1989) can help organizations to understand a range of work behaviours (van Dick et al., 2008) such as turnover (van Kinppenberg et al.,2005; Abrams et al., 1998) and commitment (Cole and Brunch, 2006). Interestingly, social influence has also been explained in many studies that the more employees identified with organizations, the more they are motivated, loyal to their organization and better performers (Bartel, 2001; Blader and Tyler, 2009; Dukerich et al., 2002; Ellemers et al., 2004; Lee et al, 2015; Mael and Ashforth, 1992).

The theoretical significance of this paper is it offers a logical reasoning on which empirical determinants and hypotheses are identified and can be tested to verify the conceptual model. Building on two social theories - the Social Identity and Social Exchange and Grunig's theory of two-way symmetrical communication, this study predicts internal symmetrical communication influences engagement of employees and simultaneously affects the components of organizational identification whereby employees with strong identification tend to have greater emotional, cognitive and physical engagement and perform better in their work. The prediction is consistent with those of Smidts et al. (2001) and Bartels et al. (2006) who found there is a positive connection between communication climate and organizational identification. It also in agreement with findings by Pugh and Dietz (2008) and Wiley et al. (2010) which showed communication plays an important role in increasing employee engagement. Moreover, the prediction corroborates the ideas of Lee et al.(2010) and Malhotra et al. (2007) who demonstrated employees with strong identification with their organization carry their job duties better than those who merely work because of contractual obligations.

Pragmatically, the new conceptual model can be helpful to organizational leaders in framing strategies to develop a competent and committed workforce that is well engaged with the organization and provides a competitive advantage. Organizations may consider using this model for managing social factor (i.e identification) and communication factor (i.e internal communication) simultaneously to have a higher level of engagement. Neglecting one of the factors would mean an organization may miss its total effectiveness and competitiveness. As concerned by Rana et al. (2014), in order to increase engagement, managers may aim to better understand their individual employees' needs and align the resources and social support with their needs. Besides that, for a better engagement, managers are also required to foster constant interactions and communication with employees since its development is a long-term and on-going process (Saks, 2006). 
In terms of aligning social support and fostering constant communication, the model's conceptualization on employee performance as the outcomes of effective internal communication and organizational identification bring practical significance in training and education for managers as well. It encourages managers to consider potential engagement effects of communication strategies and tactics (Welch, 2011) and pre-orientation identification programs for new employees (Stephens and Dailey, 2012). For example, a low emotionally engaged new employee in an orientation program may constantly communicate with peers and superiors to look for more information in order to be identified before serving his/her commitment for the organization. Certainly, these practical implications will consequent for further development of skills and training among new employees.

In conclusion, it is expected the proposed model would contribute to addressing the dearth of structured literature on the employee engagement outcomes of the correlated internal communication and organizational identification that will intrigue further reactions and discussions from scholars and practitioners. Their interest to expand this model would be beneficial in designing and implementing appropriate internal communication programs matched with appropriate type of identification to be instilled among employees for the success of organizational sustainable development.

\section{References}

Abrams, D., Ando, K., \& Hinkle, S. (1998). Psychological attachment to the group: Crosscultural differences in organizational identification and subjective norms as predictors or workers' turnover intentions. Personality and Social Psychology Bulletin, 24, 1027 $-1039$.

Albert, S., Ashforth, B. E., \& Dutton, J. E. (2000). Organizational identity and identification: Charting new waters and building new bridges. Academy of Management Review, 25(1), 13-17.

Anitha, J. (2014). Determinants of employee engagement and their impact on employee performance. International Journal of Productivity and Performance Management, 63 (3) 308 - 323. DOI: 10.1108/IJPPM-01-2013-0008

Ashforth, B. E., \& Mael, F. (1989). Social identity theory and the organization. Academy of Management Review, 14: 20-39.

Ashforth, B. E. (2001). Role transitions in organizational life: An identity-based perspective. Mahwah, NJ:Erlbaum

Ashforth, B. E., Harrison, S. H., \& Corley, K. G. (2008). Identification in organizations: An examination of four fundamental questions. Journal of Management, 34(3), 325-374.

Bakker, A.B. and Demerouti, E. (2008). Towards a model of work engagement. Career Development International, Vol. 13 No. 3, pp. 209-223.

Bakker, A.B., Albrecht, S.L. and Leiter, M.P. (2011). Key questions regarding work engagement. European Journal of Work and Organizational Psychology, Vol. 20 No. 1, pp. 4-28.

Bakker, A.B. and Schaufeli, W.B. (2008). Positive organizational behavior: engaged employees in flourishing organizations. Journal of Organizational Behavior, Vol. 29 No. 2, pp. 147-154.

Bartel, C. A. (2001). Social comparisons in boundary-spanning work: Effects of community outreach on members' organizational identity and identification. Admin. Sci. Quart. 46(3) 379-413. 
Bartels, J., Peters, O., de Jong, M., Pruyn, A., \& van der Molen, M. (2010). Horizontal and vertical communication as determinants of professional and organizational identification. Personnel Review (39:2), pp. 210-226.

Bartels, J., Pruyn, A., De Jong, M., \& Joustra, I. (2007). Multiple organizational identification levels and the impact of perceived external prestige and communication climate. Journal of Organizational Behavior, 28(2), 173-190.

Blader, S. L.\& T. R. Tyler. (2009). Testing and extending the group engagement model: Linkages between social identity, procedural justice, economic outcomes, and extrarole behavior. J. Appl. Psych. 94(2) 445-464.

Bindl, U. \& Parker, S. K. (2010). Fuelled into proactivity: How the experience of positive affect impacts on proactive self-regulation. In U. Bindl \& Chak Fu Lam (Chairs), Passion and proactivity: When and how does affect at work fuel self-initiated behaviours? Symposium conducted at the conference of the US Academy of Management, Montreal, Canada

Blau, P. M. (1964). Exchange and power in social life. New York: John Wiley

Carmeli, Abraham, Ravit Cohen-Meitar and Dov Elizur (2007). The role of job challenge and organizational identification in enhancing creative behavior among employees in the workplace. The Journal of Creative Behavior 41(2): 75-90.

Cheney, G., \& Christensen, L.T. (2001). Organizational identity: Linkages between internal and external communication. In F. M. Jablin, \& L. L. Putnam (Eds.). The new handbook of organizational communication: Advances in theory, research, and methods (pp. 231-269). Thousand Oaks, CA: Sage.

Chong, M. (2007). The role of internal communication and training in infusing corporate values and delivering brand promise: Singapore Airlines' experience. Corporate Reputation Review, Vol.10, pp. 201-212.

Cole, M.S., Brunch H. (2006) Organizational identity strength, identification, and commitment and their relationships to turnover intention: Does organizational hierarchy matter? Journal of Organizational Behavior. Vol. 27, Pp. 585-605.

Cropanzano, R., \& Mitchell, M. (2005). Social exchange theory: An interdisciplinary review. Journal of Management, 31(6), 874.

Cutlip, S., Center, A., Broom, G. (2005). Effective public relations (9th Edition). New Jersey: Prentice Hall.

Dasgupta, S.A., Suar, D. and Singh, S. (2012). Impact of managerial communication styles on employees' attitudes and behaviours. Employee Relations, Vol. 35 Issue: 2, pp.173-199.

Deaux, K., Reid, A., Mizrahi, K., \& Cotting, D. (1999). Connecting the person to the social: The functions of social identification. In T. R. Tyler, R.M. Kramer, \& O. P. John (Eds.), The psychology of the self (pp. 91-113). Hillsdale, NJ: Erlbaum.

DeConinck, J. B. (2010). The effect of organizational justice perceived organizational support, and perceived supervisor support on marketing employees' level of trust. Journal of Business Research, 63(4), 1349-1355.

Dolphin, R. R. (2005). Internal Communications: Today's Strategic Imperative. Journal of Marketing Communications, 11(3), 171-190.

Downs, C.W. \& Adrian, A.D. (2004). Assessing Organizational Communication: Strategic Communication Audits, The Guilford Press, New York, NY.

Dozier, D.M., Grunig, L.A. and Grunig, J.E. (1995). Manager's Guide to Excellence in Public Relations and Communication Management, Lawrence Erlbaum, Mahwah, NJ.

Dukerich, J. M., B. R. Golden, S. M. Shortell. 2002. Beauty is in the eye of the beholder: The impact of organizational identification, identity, and image on the cooperative behaviors of physicians. Admin. Sci. Quart. 47(3) 507-533. 
Dutton, J. E., Janet M. D. and Celia V. H. (1994). Organizational images and member identification. Administrative Science Quarterly 39 (2), 239-263.

Ellemers, N., B., Doosje, R. \& Spears (2004). Sources of respect: The effects of being liked by ingroups and outgroups. Eur. J. Soc. Psych. 34(2) 155-172

Edwards, M. R. (2005). Organizational Identification: A Conceptual and Operational Review. International Journal of Management Reviews, 7(4), 207 - 230. doi: 10.1111/j.14682370.2005.00114

Ehling, W.P., White, J. and Grunig, J.E. (1992). Public relations and marketing practices, in Grunig, J.E. (Ed.), Excellence in Public Relations and Communication Management, Lawrence Erlbaum Associates, Hillsdale, NJ, pp. 357-383.

Eisenberger, R., Armeli, S., Rexwinkel, B., Lynch, P. D., \& Rhoades, L. (2001). Reciprocation of perceived organizational support. Journal of Applied Psychology, $86,42-51$.

Emerson, R. M. (1976). Social exchange theory. Annual Review of Sociology, 2(1), 335-362.

Epitropaki, O. (2013). A multi-level investigation of psychological contract breach and organizational identification through the lens of perceived organizational membership: Testing a moderated-mediated model. Journal of Organizational Behavior, 34, 65-86. doi: 10.1002/job.1793

Fuller, J.B., Marlera, L., Hesterb, K., Freyb, L. and Relyeab, C. (2006a). Construed external image and organizational identification: a test of the moderating influence of need for self-esteem. The Journal of Social Psychology, Vol. 146 No. 6, pp. 701-16.

Gersick, C. J., Dutton, J. E., \& Bartunek, J. M. (2000). Learning from academia: The importance of relationships in professional life. Academy of Management Journal, 43(6), 1026-1044

Goldhaber, G.M. (1993). Organizational Communication. 6th ed., McGraw-Hill, New York, NY.

Gronstedt, A. (2000). The Customer Century: Lessons from World Class Companies in Integrated Marketing and Communications. Routledge, New York.

Grunig, J. E. (1989). Symmetrical presuppositions as a framework for public relations theory. In C. H. Botan \& V. Hazleton, Jr. (Eds.), Public relations theory (pp. 17-44). Hillsdale: Lawrence Erlbaum.

Grunig, J.E. (ed.) (1992). Excellence in public relations and communication management. Hillsdale, NJ: Lawrence Erlbaum.

Grunig, J.E. (2001). Two-way symmetrical public relations: past, present, and future. In Heath, R.L. (Ed.), Handbook of Public Relations, Sage, Thousand Oaks, CA, pp. 1132.

Grunig, L. A., Grunig, J. E., \& Dozier, D. M. (2002). Excellent public relations and effective organizations. A study of communication management in three countries. Mahwah, NJ: Lawrence Erlbaum.

Haslam, S. A. (2001). Psychology in organizations: The social identity approach. London: Sage.

Hogg, M. A. (2000). Subjective uncertainty reduction through self-categorization: A motivational theory of social identity processes. European Review of Social Psychology, 11, 223-255

Jiang, H. and Men, L.R. (2015). Creating an engaged workforce: the impact of authentic leadership, transparent organizational communication, and work-life enrichment. Communication Research, available at: https://doi.org/10.1177/0093650215613137 
Jo, S. and Shim, Y. (2004). Media or Personal Relations? Exploring Media Relations Dimensions in South Korea, Journalism and Mass Communication Quarterly, Vol. 81 n. 2, pp. 292-306.

Kahn W.A (1990). Psychological conditions of personal engagement and disengagement at work. Academy of Management Journal, 33(4), 692-724.

Kalla, H. K. (2005). Integrated Internal Communications: A Multidisciplinary Perspective. Corporate Communications: An International Journal, 10(4), 302-314.

Kang, M. and Sung, M. (2017). How symmetrical employee communication leads to employee engagement and positive employee communication behaviours: The mediation of employee organization relationships. Journal of Communication Management, Vol. 21 Issue: 1, pp.82-102.

Karanges, E., Beatson, A., Johnston, K. \& Lings, I. (2014). Optimizing employee engagement with internal communication: A social exchange perspective, in Journal of Business Marketing Management, 7 (2), 329-353.

Karanika-Murray, M., Duncan, N., Pontes, H. M., \& Griffiths, M. D. (2015). Organizational identification, work engagement, and job satisfaction. Journal of Managerial Psychology, 30(8), 1019-1033.

Kennan, W. R., \& Hazleton, V. (2006). Internal public relations, social capital, and the role of effective organizational communication. In C. H. Botan \& V. Hazleton (Eds.), Public relations theory II (pp. 311-340). Mahwah, NJ: Lawrence Erlbaum.

Kim, J.-N. and Rhee, Y. (2011). Strategic thinking about employee communication behavior (ECB) in public relations: testing the models of megaphoning and scouting effects in Korea. Journal of Public Relations Research, Vol. 23 No. 3, pp. 243-268.

Kreps, G. L. (1989). Reflexivity and internal public relations: The role of information in directing organizational development. In C. H. Botan and V. Hazleton, Jr., Public relations theory (pp. 265-279). Hillsdale, NJ: Lawrence Erlbaum.

Kress, N. (2005). Engaging your employees through the power of communication. Workspan, Vol. 48, No. 5, pp. 26-36.

Lee, E.-S., Park, T.-Y., \& Koo, B. (2015). Identifying Organizational Identification as a Basis for Attitudes and Behaviors: A Meta-Analytic Review. Psychological Bulletin, 141(5), 1049-1080.

Lockwood NR (2007). Leveraging employee engagement for competitive advantage: HR's strategic role. Society for Human Resource Management Quarterly, 1/4

Mael, F., \& Ashforth, B. E. (1992). Alumni and Their Alma Mater: A Partial Test of the Reformulated Model of Organizational Identification. Journal of Organizational Behavior, 13(2), 103-123.

Macey, W.H. and Schneider, B. (2008), The meaning of employee engagement. Industrial and Organizational Psychology. Vol. 1 No. 1, pp. 3-30.

Malhotra, N., Budhwar, P. and Prowse, P. (2007). Linking Rewards to Commitment: An Empirical Investigation of Four UK Call Centres. International Journal of Human Resource Management, 18, 12, 2095-2128.

Men, L. R. (2014). Strategic Internal Communication: Transformational Leadership, Communication Channels, and Employee Satisfaction. Management Communication Quarterly, 28, 2, pp. 264-284.

Meng, J., B.K. and Berger (2012). Measuring return on investment (ROI) of organizations' internal communication efforts. Journal of Communication Management, 16(4), 332354.

Mishra, K., Boynton, L., \& Mishra, A. (2014). Driving Employee Engagement The Expanded Role of Internal Communications. International Journal of Business Communication, 51(2), 183-202 
Mohr, Jakki and John Nevin (1990). Communication Strategies in Marketing Channels: A Theoretical Perspective. Journal of Marketing, 50 (October), 36-51.

Morris, E. (2010). Dell goes mobile to bolster its employee engagement. PRWeek, Vol. 13 No. 2, pp. 14-15.

Nazir, O. and Islam, J. U. (2017). Enhancing organizational commitment and employee performance through employee engagement: An empirical check. South Asian Journal of Business Studies, 6 (1), pp.98-114.

O'Reilly, C. A., \& Chatman, J. (1986). Organizational commitment and psychological attachment: The effects of compliance, identification, and internalization on prosocial behavior. Journal of Applied Psychology, 71, 492-499.

Postmes, T. (2003). A Social Identity approach to communication in organization. In S.A. Haslam, D. van Knippenberg, M.J Platow \& N. Ellemers (Eds.). Social Identity at work: Developing theory for organizational practice (pp. 81-97). Philadelphia; Psychology Press.

Postmes, T. (2014). A Social Identity Approach to Communication in Organizations. https://www.researchgate.net/publication/237419884

Postmes T, Spears R, Cihangir S. (2001). Quality of decision making and group norms. Journal of Personality and Social Psychology 80: 918-930.

Pugh, S. D. \& Dietz, J. (2008). Employee engagement at the organizational level of analysis. Industrial and Organizational Psychology: Perspectives on Science and Practice, (1), 44--47.

Rana, S., Ardichvili, A. \& Tkachenko, O. (2014). A theoretical model of the antecedents and outcomes of employee engagement. Journal of Workplace Learning 26(3/4), 249-266

Reade, C. (2001). Antecedents of organizational identification in multinational corporations: fostering psychological attachment to the local subsidiary and the global organization. Journal of Human Resource Management, 12(8), 1269 - 1291. doi: 10.1080/09585190110083794

Restubog, S.L.D., Hornsey, M.J., Bordia, P. and Esposo, S. R. (2008), Effects of psychological contract breach on organizational citizenship behaviour: Insights from the group value model, Journal of Management Studies, Vol. 45, No. 8, pp. 13771400 .

Riketta, M. (2005). Organizational Identification: A Meta-Analysis. Journal of Vocational Behavior, 66, 358-384.

Rich, B.L., Lepine, J.A. and Crawford, E.R. (2010). Job engagement: antecedents and effects on job performance. Academy of Management Journal, Vol. 53 No. 3, pp. 617-635.

Ruck, K. \& Welch, M. (2012). Valuing internal communication; management and employee perspectives. Public Relations Review, 38 (2), 294-302.

Saks, A. M. (2006). Antecedents and Consequences of Employee Engagement. In Journal of Managerial Psychology, 21(6), 600-619

Schaufeli, W.B., Salanova, M., Gonzalez-Roma, V. and Bakker, A.B. (2002). The measurement of engagement and burnout: a two-sample confirmatory factor analytic approach. Journal of Happiness Studies, Vol. 3, pp. 71-92.

Schaufeli, W. B., Taris, T. W., \& Van Rhenen, W. (2008). Workaholism, burnout and engagement: Three of a kind or three different kinds of employee well-being? Applied Psychology: An International Review, 57, 173-203.

Shuck, M. B., \& Wollard, K. (2010). Employee engagement \& HRD: A seminal review of the foundations. Human Resource Development Review, 9(1), 89-110. doi:10.1177/1534484309353560 
Sluss, D. M., Klimchak, M., \& Holmes, J. J. (2008). Perceived organizational support as a mediator between relational exchange and organizational identification. Journal of Vocational Behavior, 73(3), 457-464.

Smidts, A., Pruyn, A., \& Riel, C. (2001). The impact of employee communication and perceived external prestige on organizational identification. Academy of Management Journal, 49(5), 1051-1062.

Stephens, K. K., \& Dailey, S. (2012). Situated organizational identification in newcomers: Impacts of preentry organizational exposure. Management Communication Quarterly, 26, 402-422.

Tajfel, H. (1978). Social categorization, social identity, and social comparison. In H. Tajfel (Ed.), Differentiation between Social Groups: Studies in the Social Psychology of Intergroup Relations (pp. 61-76). London: Academic Press.

Tajfel, H., \& Turner, J. C. (1985) The social identity theory of intergroup behavior. In S. Worchel \& W. G. Austin (Eds.), Psychology of intergroup relations (2nd ed., pp. 724). Chicago: Nelson-Hall.

Truss C, Soane E, Edwards C, Wisdom K, Croll A, Burnett J (2006). Working Life: Employee Attitudes and Engagement 2006, Chartered Institute of Personnel and Development, London, UK. ISBN 9781843981794

Tyler, T. R., Blader, S., (2001). Identity and cooperative behaviour in groups. Group processes \& intergroup relations, Vol.4, $\mathrm{N}^{\circ} 3$, p.207-226.

Van Dick, R., Van Knippenberg, D., Hägele, S., Guillaume, Y. R. F., \& Brodbeck, F.C. (2008). Group diversity and group identification: The moderating role of diversity beliefs. Human Relations, 61(10), 1463-1492.

Van Knippenberg, D., van Knippenberg, B., \& De Cremer, D. (2005). Extending the social identity model of leadership: The interactive effects of leader prototypicality and leader procedural fairness. Paper presented at the XIIth European Congress of Work and Organizational Psychology, Istanbul, Turkey

Van Knippenberg, D., Van Schie, E. C. M. (2000). Foci and correlates of organizational identification. Journal of Occupational and Organizational Psychology, 73, 137-147.

Van Riel, C. (1995). Principles of Corporate Communication, Prentice-Hall, Harlow.

Weick, K.E., \& Roberts, K.H. (1993). "Collective mind in organizations: Heedful interrelating on $\mathrm{fl}$ ight decks. Administrative Science Quarterly, 38, 357-381.

Welch M. (2011). The evolution of the employee engagement concept: communication implications. Corporate Communications: An International Journal, Vol. 16 Issue: 4, pp.328-346

Welch, M. and Jackson, P.R. (2007). Rethinking internal communication: a stakeholder approach. Corporate Communications: An International Journal, Vol. 12 No. 2, pp. 177-198.

Wiley, J.W., Kowske, B.J. and Herman, A.E. (2010). Developing and validating a global model of employee engagement. in Albrecht, S.L. (Ed.). Handbook of Employee Engagement: Perspectives, Issues, Research and Practice. Edward Elgar. Cheltenham.

Yates, K. (2006). Internal communication effectiveness enhances bottom-line results. Journal of Organizational Excellence. Summer, 71-79. 